\title{
Bottom Fish Assemblages at the Shelf and Continental Slope off East Greenland
}

\author{
O. A. Jørgensen* \\ Greenland Institute of Natural Resources $\backslash$ DTU Aqua, Technical University of Denmark, \\ Charlottenlund Slot, DK 2920 Charlottenlund, Denmark \\ *Corresponding author. Tel.: +45 35883300; olj@aqua.dtu.dk \\ C. Hvingel \\ Institute of Marine Research P.O. Box. 6404, N-9294 Tromsø, Norway, \\ P. R. Møller \\ Zoological Museum, University of Copenhagen. DK 2100, Copenhagen Ø, Denmark \\ JØRGENSEN, O. A., C. HVINGEL, and P. R. MØLLER. 2015. Bottom Fish Assemblages at the Shelf \\ and Continental Slope off East Greenland. J. Northw. Atl. Fish. Sci., 47: 37-55. doi:10.2960/J.v47.m706
}

\begin{abstract}
During 2006 and 2008 two bottom trawl surveys were conducted at East Greenland to $72^{\circ} \mathrm{N}$ covering depths down to $1500 \mathrm{~m}$. In the 149 trawl hauls in total 113 fish species were recorded of which 37 were considered pelagic and excluded from the analyses. As a first step the abundance data for the 76 benthic species were used for analyses of the fish fauna diversity and fish assemblages. Nine assemblages were found by a standard type of cluster analysis. A Bayesian multinomial logit model was then applied to calculate vectors of probabilities defining the likelihood of each haul belonging to each of the nine clusters. By means of a geostatistical tool the spatial distribution of the conditional probabilities for each cluster (assemblage) was mapped. Each of the nine assemblages was further defined by indicator species, depth and temperature. The assemblages were well defined regarding geographical distribution, species composition, temperature and depth. Three of the assemblages were located in the cold Iceland Sea while six were found in the somewhat warmer Irminger Sea.
\end{abstract}

Keywords: Bayesian multinomial logit model, East Greenland, bottom fish assemblage, mapping

\section{Introduction}

The water masses in the Iceland Sea and the Irminger Sea are to some extend separated by a submarine ridge between Iceland and Greenland (Dohrn Bank) with a maximum depth of $630 \mathrm{~m}$ (Fig.1). In the shelf area closest to East Greenland north of the ridge the hydrographical conditions are dominated by the southward flowing cold East Greenland Current which, to a large extend, is composed of Norwegian Deep Sea Water with temperatures often below $0^{\circ} \mathrm{C}$ (Buch, 2000). The hydrographical conditions in the southern part of the Denmark Strait and the Irminger Sea are influenced by two main currents bringing water masses of different origin into the area. The shelf is influenced by the cold East Greenland Current while the continental slope is dominated by inflow of warm $\left(3.5-4.5^{\circ} \mathrm{C}\right)$, water from the Irminger Sea. The middle and lower part of the slope in the Irminger Sea is, however, also influenced by overflow over the submarine ridge of Northwest Atlantic Bottom Water (about $1^{\circ} \mathrm{C}$ ) formed by cold Norwegian Deep-Sea Water.
Very little research on the total fish fauna and its distribution has been conducted in East Greenland waters. Haedrich and Kreft (1978) described the distribution of bottom fishes in the Denmark Strait and Irminger Sea based on 27 trawl hauls of which only about half were in East Greenland waters. Rätz (1999) identified a number of assemblages at depths between 0 and $400 \mathrm{~m}$ but his analyses were focused on commercial species. In recent years a number of checklist have been published covering also East Greenland waters (Møller et al., 2010, Mecklenburg et al., 2011, Christiansen et al., 2013), but none of these treat the detailed diversity and structure in the East Greenland fish fauna. The structure of the West Greenland fish fauna is better known due to detailed studies by e.g. Jørgensen et al. (2005, 2011),

In 2006 Greenland Institute of Natural Resources (GINR) conducted a bottom trawl survey between $67^{\circ} \mathrm{N}$ (north of Dohrn Bank) to $72^{\circ} \mathrm{N}$ including 10 trawl stations in Scoresby Sound and in 2008 GINR, for the first time, conducted a bottom trawl survey that covered both the 
shelf and the continental slope between $59^{\circ} 45^{\prime} \mathrm{N}$ (Cape Farwell) and $67^{\circ} \mathrm{N}$ (Fig.1). Both surveys covered depths down to about $1500 \mathrm{~m}$.

The purpose of the present study is to identify and describe fish assemblages at East Greenland and provide a baseline study in a region from which there is very little information and that is experiencing environmental changes owing to climate changes and that is under steadily anthropogenic impact mainly in the form of commercial fishery. The study will give a basis for a better understanding of spatial and temporal variability in the ecosystem in the future. This is done by identifying and mapping bottom fish assemblages by methods that are reproducible, hence future changes in assemblage composition and distribution can be statistically tested. The approach makes the results comparable to similar studies have been conducted in the Davis Strait (Jørgensen et al., 2005) and in the Baffin Bay (Jørgensen et al., 2011).

\section{Material and methods}

Two depth stratified random bottom trawl surveys were conducted at East Greenland between $59^{\circ} 42^{\prime} \mathrm{N}$ and $71^{\circ} 54^{\prime} \mathrm{N}$, with a total of 151 valid stations (Fig. 1). The survey area was stratified in $200 \mathrm{~m}$ depth intervals except a stratum from 1401-1500 m. Each stratum was allocated at least two hauls. The hauls were allocated by a method that combines the use of a minimum between-stations-distance rule (buffer zone) with a random allocation scheme (Kingsley et al. 2004). Both surveys were conducted by GINR's R/V Paamiut (722 gross tons).

During 16-26 September, 2006, 52 stations, including 10 stations in Scoresby Sound, were sampled north of Dohrn Bank (Northern area in Fig. 1), using an Alfredo III bottom trawl with a mesh size of $140 \mathrm{~mm}$ and a $30-\mathrm{mm}$ meshliner in the cod-end. Further, 99 stations were sampled between Dohrn Bank and Cape Farwell (Southern area in Fig. 1) during 18 August - 13 September, 2008, using a Cosmos 2000 shrimp trawl with a $20-\mathrm{mm}$ meshliner in the cod end at depths $<600 \mathrm{~m}$ and an Alfredo III trawl at depths $>400 \mathrm{~m}$. Both trawls were mounted with a rock hopper type ground gear. Towing speed was between 2.5 and 3 knots and towing time between 15 and 30 min. The exact wingspread, towing speed and towing time was recorded for each tow. The depth of the trawling ranged from 118-1460 m. Near-bottom temperatures were measured at all trawl stations, in $0.1^{\circ} \mathrm{C}$ increments, by a Seamon sensor (Starr-Oddi, 104 Reykjavik, Iceland) mounted on a trawl door. The catch at each station was sorted by species, counted and weighed to the nearest 0.1 $\mathrm{kg}$. In total, 37 species considered as pelagic according to Whitehead et al. (1984-1986) were excluded from the analyses because an unknown fraction of the captured specimens might have been taken during setting and hauling of the trawl (Appendix A).

Abundance estimates were standardized to $1 \mathrm{~km}^{2}$ swept area prior to further calculations using the exact wing spread, towing speed and towing time. The catchability is unknown and likely varies from species to species but in the present analysis it is set to 1.0, i.e., all demersal fish within the trawled area were caught.

To identify fish assemblages within the survey area and to construct a map of their distribution, an approach somewhat similar the one proposed by Souissi et al., (2001) and further developed by Jørgensen et al. (2005) was applied. By means of a Bayesian multinomial logit model (Congdon, 2001) the probability that individual samples (trawl hauls), characterized by the particular composition of species and their abundances, belong to each of the groups of hauls (Assemblages) as defined by a multivariate cluster analysis was quantified. Each haul could thus be characterized by a geographical position and

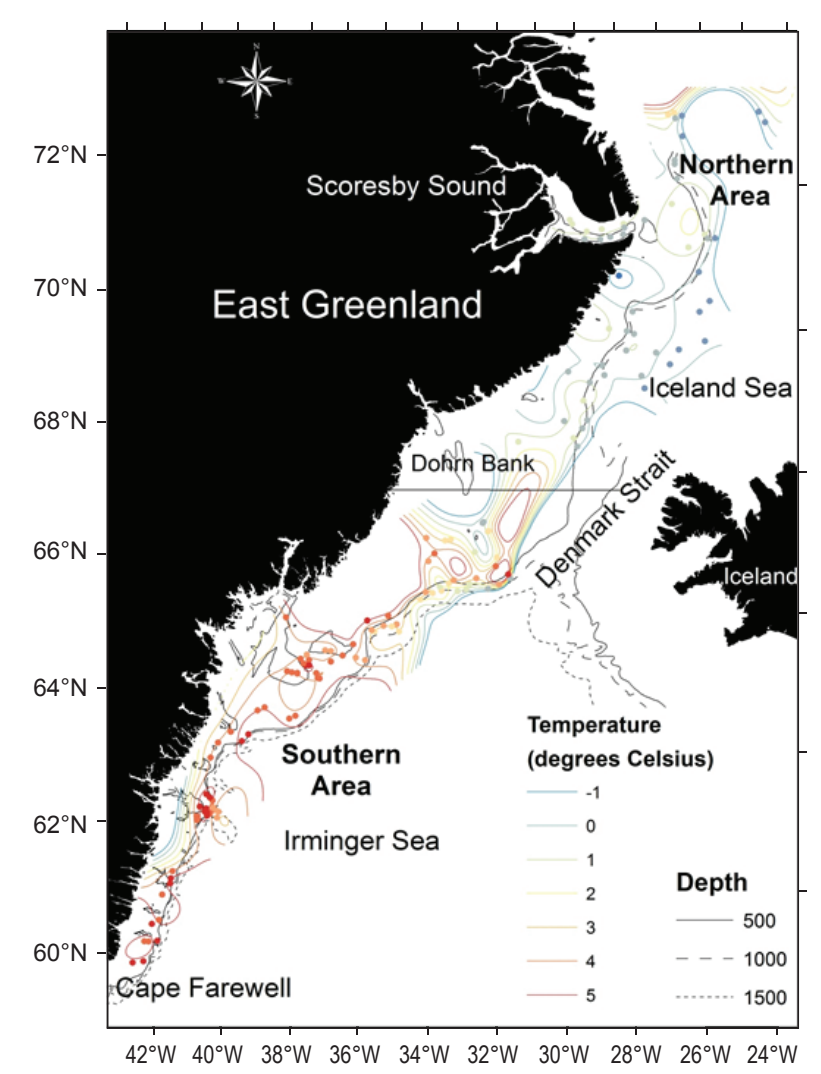

Fig 1. Survey area with distribution of trawl stations, indication of the northern and southern area (see text) and distribution of bottom temperatures based on interpolation by the spline method (regularized), with a weight of 0.1 and 12 points and a cell size on $5 \times 5 \mathrm{~km}$. 
a vector of group membership probabilities. This provided the basis for drawing a continuous map of distribution using kriging (see below).

To reduce "noise", we selected only demersal species that were represented in more than $5 \%$ of the tows for analyses. The sum of the total abundance was estimated and species contributing more than $0.1 \%$ of the total sum were considered as primary species $(n=25)$, whereas the remaining were classified as secondary species $(n=12)$. The remaining 39 rare species (observed in less than 5\% of the hauls (8)), of the 76 demersal species recorded, are not included in the analyses, but ranges of recorded depth, temperature and latitude are provided for all species in Appendix A.

Two stations were excluded from the assemblage analysis because they did not include any "Primary species". In total, 149 stations were hence used for further analysis.

\section{Cluster analysis}

The cluster analysis is a numerical rather than a statistical procedure and no assumption of normality is required. However, the data were transformed by a double square root in order to stabilize the variance and hence make the cluster analysis more robust. Further, the fourth root transform handles zeroes quite well as compared to log transforms which requires adding a subjectively chosen positive.

In the first step, the individual trawl hauls represented by data vectors (root four transformed counts of individuals of the 25 primary species $\mathrm{km}^{-2}$ ) were analysed by multivariate cluster analysis using the Primer software v. 5.2 (Primer, 2001). The similarity coefficients between sites (trawl stations) were estimated by means of the BrayCurtis clustering method (Legendre and Legendre, 1998).

The hierarchical tree obtained from the cluster analysis was split stepwise into an increasing number of "cut off levels", each time expanding the spatial organization patterns of the assemblages by one (i.e., the first "cut off level" split the data set in two clusters, the second in three and so on). The procedure was stopped when there was no further increase in the "indicator values" (see Characterization of the assemblages (indicator values) below) indicating that no additional information was obtained by further subdividing the data set. (see Appendix 2 for the stepwise hierarchical split and Jørgensen et al., 2005)

\section{Bayesian multinomial logit model}

Once the numbers of clusters and their members have been determined, a probability that an individual haul is drawn from each of the clusters can be calculated. This was done using Bayesian multinomial logit model described by (Congdon 2001) and the mathematical formulation used for the present estimations is given in Jørgensen et al. (2005).

\section{Spatial distribution of assemblages}

A map of assemblage distribution could be constructed from the estimated probability vectors assigned to the geographical position of the haul. An interpolated regular grid, 0.025 longitude by 0.025 latitude degrees, was obtained by using a spherical variogram model and the kriging method (Matheron 1962, Souissi et al., 2001).

The kriging procedure provides estimates far from points with observations and thus also for areas that cannot be considered represented by the survey. Hence we have chosen to mask the maps of the conditional probabilities at approximately the $1700 \mathrm{~m}$ depth contours, a few hundred meters beyond the area covered by the surveys. All stations have a probability to belong to one of the nine clusters, although it often is very low. In order to improve the graphical representation areas with less than 15\% conditional probability have been removed.

\section{Characterization of the assemblages (indicator values)}

Dufrêne and Legendre (1997) defined an index which was maximum $(100 \%)$ when the individuals of a particular species are observed in all sites (trawl hauls) of only one assemblage; therefore the indicator value (IV) for any given species will be highest for the assemblage where it occurs in the greatest number of sites and this species could then be considered an "indicator species" for that assemblage. The indicator values were calculated for all primary and secondary species across all "cut-off levels" and assemblages after the reallocation of hauls (Jørgensen et al., 2005).

The indicator values were also used to assess the benefit of adding additional "cut-off-levels" to the initial cluster analysis. When no increase in indicator value was observed for any species no additional "cut-off-levels" were applied.

Mean temperature and depth with Standard Deviation and $95 \%$ confidence intervals is estimated by assemblage.

\section{Results}

A total of 113 fish species were recorded during the surveys, of which 37 were considered pelagic and excluded from the analysis (Appendix 1). 
The cluster analysis based on the 25 primary species defined nine groups of hauls with similar species composition and density. The indicator values calculated for each species (before the reallocation of stations) within these nine clusters suggested that no additional information could be obtained by further separating the data i.e. the maximum indicator value observed for any given species did not increase by adding another "cut-off level".

The reallocation of hauls to the cluster to which they showed the highest probability of membership resulted in nine different assemblages with a rather well defined geographic distribution with statistically significant differences in mean depth or temperature or both.

The first "cut-off level" separates the nine groups in two, one with three groups or assemblages containing hauls all located in the Iceland Sea north of Dohrn Bank (Northern area in Fig 1), and one with six assemblages containing hauls all, except one, located in the Irminger Sea south of Dohrn Bank (Southern area Fig.1).

\section{Iceland Sea}

Assemblage 1 is located in deep (mean $1148 \mathrm{~m}$ ) cold water (mean $0.0^{\circ} \mathrm{C}$ ) on the slope (Fig 2; Table 1). Gaidropsarus argentatus $(\mathrm{IV}=66.3)$ is the primary indicator species for this area where Amblyraja hyperborea also is an important species. The species Lycodes paamiuti (IV=15.6), Paraliparis bathybius (IV=33.6) and Rhodichthys regina $(I V=24.8)$ are secondary indicator species and are almost exclusively found in this area. Otherwise there are relatively few species here (Table 1).

Assemblage 2 is located in relatively shallow water (mean $485 \mathrm{~m}$ ) with a mean temperature on $0.9^{\circ} \mathrm{C}$ along the coast and in Scoresby Sound. Triglops nybelini $(\mathrm{IV}=90.2)$ and

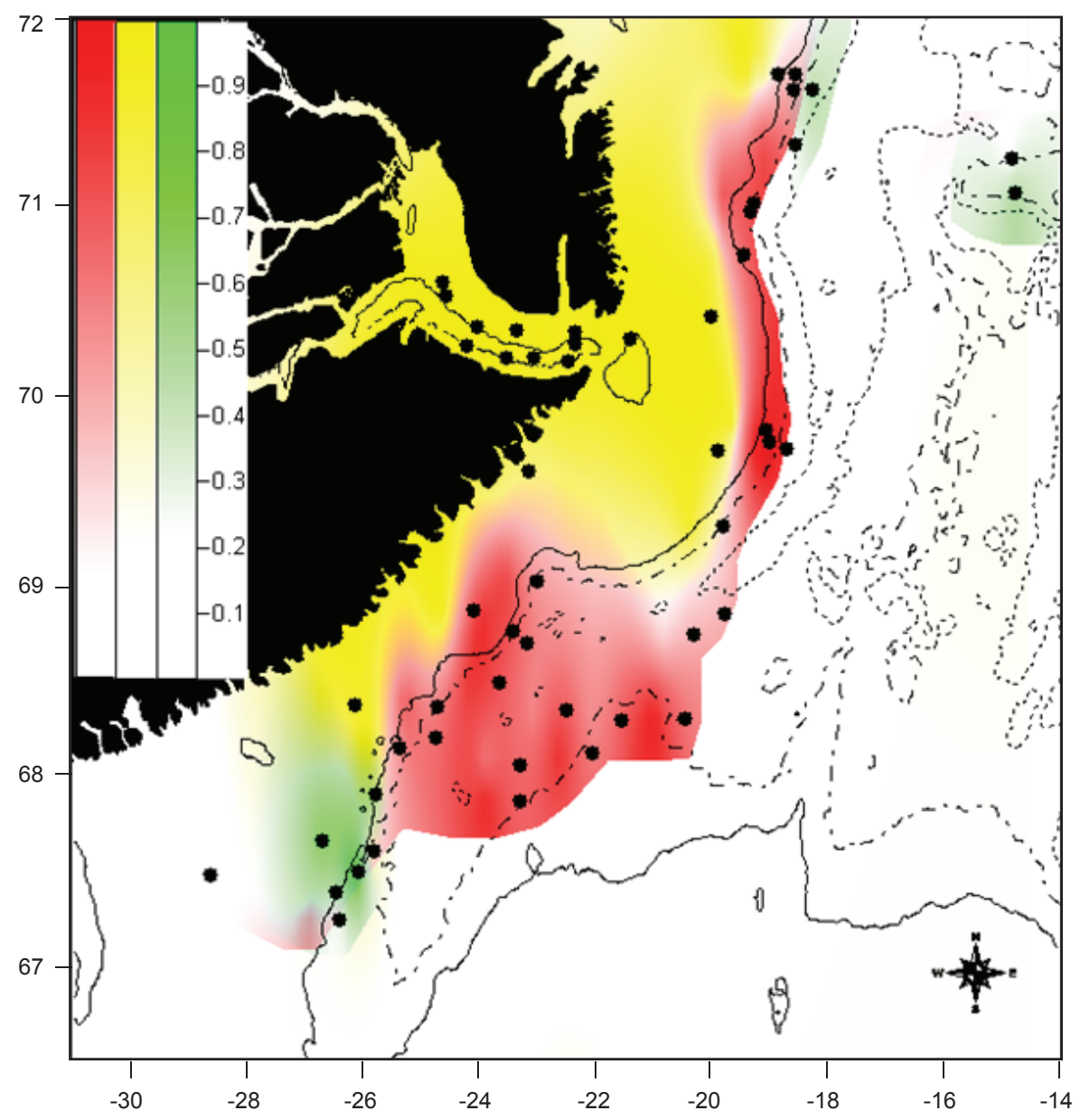

Fig 2. Northern area. Iso-probability map representing the spatial distribution of the possibility of belonging to Assemblages 1-3. 1:) 2:) 3:). Depth contours: $500 \mathrm{~m}$ solid, $1000 \mathrm{~m}$ dashed $1500 \mathrm{~m}$ dotted. 
JØRGENSEN et al: : Bottom Fish Assemblages at the Shelf and Continental Slope off East Greenland

Table 1. Indicator values for primary and secondary indicator species and mean depth (m) and temperature ${ }^{\circ} \mathrm{C}$ with standard deviation and $95 \%$ confidence intervals by assemblage. $\mathrm{n}=$ number of hauls. Indicator species are given in bold.

\begin{tabular}{|c|c|c|c|c|c|c|c|c|c|}
\hline Assemblage & 1 & 2 & 3 & 4 & 5 & 6 & 7 & 8 & 9 \\
\hline $\mathrm{n}$ & 20 & 23 & 8 & 10 & 16 & 14 & 17 & 11 & 30 \\
\hline \multirow{3}{*}{ Temperature } & 0.0 & 0.9 & 0.7 & 4.0 & 2.4 & 4.5 & 3.6 & 4.4 & 4.1 \\
\hline & 0.4 & 0.7 & 0.7 & 0.7 & 1.2 & 0.6 & 1.4 & 1.1 & 1.2 \\
\hline & 0.2 & 0.3 & 0.5 & 0.4 & 0.6 & 0.3 & 0.7 & 0.7 & 0.4 \\
\hline \multirow[t]{4}{*}{ Depth } & 1148.0 & 484.6 & 643.5 & 1110.4 & 835.3 & 404.3 & 599.9 & 190.4 & 311.6 \\
\hline & 238.4 & 185.3 & 286.8 & 219.1 & 118.6 & 40.1 & 139.5 & 36.2 & 90.9 \\
\hline & 104.5 & 75.7 & 198.7 & 135.8 & 58.1 & 21.0 & 66.3 & 21.4 & 32.5 \\
\hline & \multicolumn{9}{|c|}{ Indicator values } \\
\hline Centroscyllium fabricii & 0 & 0 & 0 & 27.4 & 15.4 & 0 & 1 & 0 & 0 \\
\hline Amblyraja fyllae & 0 & 0 & 0 & 0.7 & 1.6 & 23.3 & 19.6 & 0 & 0 \\
\hline Amblyraja hyperborea & 56.3 & 7.3 & 21.5 & 0.2 & 0 & 0 & 0 & 0 & 0 \\
\hline Amblyraja radiata & 0 & 13.3 & 3.2 & 0.4 & 1.8 & 1.2 & 24.2 & 0 & 0.8 \\
\hline Synaphobranchus kaupi & 0 & 0 & 0 & 95.7 & 1.3 & 0 & 0 & 0 & 0 \\
\hline Notacanthus chemnitzii & 0 & 0 & 0 & 9.3 & 56 & 0 & 0 & 0 & 0 \\
\hline Trachyrhynchus murrayi & 0 & 0 & 0 & 70 & 0 & 0 & 0 & 0 & 0 \\
\hline Coryphaenoides rupestris & 0 & 0 & 0 & 97.2 & 0.9 & 0 & 0 & 0 & 0 \\
\hline Macrourus berglax & 0.1 & 0 & 1.7 & 39.6 & 48.9 & 0.3 & 2.2 & 0 & 3.2 \\
\hline Gadus morhua & 0 & 0 & 0 & 0 & 0 & 7.5 & 0 & 73.8 & 15.6 \\
\hline Melanogrammus aeglefinus & 0 & 0 & 0 & 0 & 0 & 0 & 0 & 5.8 & 44.6 \\
\hline Gaidropsarus argentatus & 66.3 & 0.1 & 24 & 0.4 & 8.2 & 0.5 & 0.5 & 0.1 & 0 \\
\hline Molva dipterygia & 0 & 0 & 0 & 9 & 2.3 & 50.3 & 1.9 & 0 & 0.8 \\
\hline Antimora rostrata & 0 & 0 & 0 & 99.6 & 0 & 0 & 0 & 0 & 0 \\
\hline Lepidion eques & 0 & 0 & 0 & 25.7 & 4.2 & 0 & 8.5 & 0 & 0 \\
\hline Anarhichas lupus & 0 & 0 & 0 & 0 & 0 & 2.9 & 0 & 18.7 & 24.7 \\
\hline Sebastes mentella & 0 & 0 & 0 & 0 & 1.5 & 90 & 7.6 & 0 & 3.1 \\
\hline Sebastes marinus & 0 & 0 & 0 & 0.1 & 0 & 20.5 & 0 & 2.8 & 64.8 \\
\hline Artediellus atlanticus & 0 & 52.4 & 5.2 & 0 & 0 & 0 & 0 & 0.6 & 0.1 \\
\hline Triglops murrayi & 0 & 0 & 0 & 0 & 0 & 1.3 & 0.2 & 13.8 & 8.4 \\
\hline Triglops nybelini & 0 & 90.2 & 0 & 0 & 0 & 0 & 0 & 0.2 & 0 \\
\hline Cottunculus microps & 2.6 & 5.8 & 63.3 & 0 & 0.1 & 0.3 & 0.6 & 0 & 0.1 \\
\hline Liparis fabricii & 3.3 & 74.2 & 0 & 0 & 0 & 0 & 0 & 0 & 0 \\
\hline Hippoglossoides platessoides & 0 & 1 & 0 & 0 & 0 & 11.4 & 1.2 & 12.5 & 33.6 \\
\hline Reinhardtius hippoglossoides & 0 & 9 & 15.7 & 73.2 & 5.2 & 0.1 & 7.3 & 0 & 0.6 \\
\hline \multicolumn{10}{|l|}{ Secondary species } \\
\hline Bathyraja spinicauda & 0 & 0 & 0 & 3.5 & 29.1 & 2.8 & 1 & 0 & 0 \\
\hline Brosme brosme & 0 & 0 & 0 & 0 & 5.2 & 14.3 & 3.2 & 0 & 4.9 \\
\hline Anarhichas denticulatus & 0 & 0 & 0 & 5.2 & 5.3 & 8.5 & 5.9 & 0.8 & 5.7 \\
\hline
\end{tabular}


lable 1 cont'd

\begin{tabular}{lrrrrrrrrr} 
Anarhichas minor & 0 & 0 & 8.1 & 1.1 & 0 & 6.1 & 0.1 & 5.4 & 10.2 \\
Lycodes eudipleurostictus & 10.7 & 10.4 & 0.7 & 0 & 0.6 & 0 & 3.2 & 0 & 0.7 \\
Lycodes paamiuti & $\mathbf{1 5 . 6}$ & 0 & 2.8 & 0 & 0.7 & 0 & 0 & 0 & 0.3 \\
Lycodes pallidus & 6 & 10.4 & 1 & 0 & 0 & 0 & 2.6 & 0 & 0.7 \\
Lycodes reticulatus & 0 & 16.8 & 13.9 & 0 & 0 & 0 & 0 & 0 & 0.1 \\
Lycodes seminudus & 5.4 & 2.9 & 5.9 & 0 & 0 & 0 & 1.9 & 0 & 0.3 \\
Leptagonus decagonus & 0 & $\mathbf{4 0 . 1}$ & 0 & 0 & 0 & 0 & 0.4 & 0 & 0.2 \\
Careproctus reinhardti & 24.8 & 4.8 & 15.6 & 0 & 0 & 0 & 0 & 0 & 0 \\
Paraliparis bathybius & $\mathbf{3 3 . 6}$ & 0 & 0 & 1 & 0 & 0 & 0 & 0 & 0 \\
Rhodichthys regina & $\mathbf{2 4 . 8}$ & 0 & 15.3 & 0 & 0 & 0 & 0 & 0 & 0 \\
\hline
\end{tabular}

Liparis fabricii $(\mathrm{IV}=74.2)$ are primary indicator species in this assemblage where Artediellus atlanticus is common, too (Fig. 2; Table 1). Leptagonus decagonus is secondary indicator species in this assemblage.

Assemblage 3 is a group of eight hauls somewhat scattered in the area at intermediate depth (mean $644 \mathrm{~m}$ ) and with a mean temperature at $0.7^{\circ} \mathrm{C}$. Cottunculus microps is primary indicator species $(\mathrm{IV}=63.3)$ for this assemblage and the commercially important species Reinhardtius hippoglossoides has also its highest densities in the northern area in this assemblage although the indicator value is low $(\mathrm{IV}=15.7)$. Otherwise the assemblage is characterised by few primary species with low indicator values (Fig. 2, Table 1). Assemblage 3 is separated from the deeper Assemblage 1 by the high presence of Cottunculus microps and Reinhardtius hippoglossoides and relative low presence of Gaidropsarus argentatus and Amblyraja hyperborea and from the shallow Assemblage 2 by the presence Cottunculus microps and the absence of Triglops nybelini and Liparis fabricii.

\section{Irminger Sea}

Six of the nine assemblages are located in the Irminger Sea. Some of the assemblage have mean depths close to the assemblages defined in the Iceland Sea but the mean temperature is statistically significant (95\% level) higher in all assemblages (Table 1).

Assemblage 4 is the deepest located assemblage in the southern area and is a rather well defined group of ten hauls at deep (mean $1110 \mathrm{~m}$ ) and relatively warm water $\left(4.0^{\circ} \mathrm{C}\right)$. The primary indicator species are the common deep water species Antimora rostrata $(\mathrm{IV}=99.6)$, Coryphaenoides rupestris (IV=97.2), Synaphobranchus kaupi $(\mathrm{IV}=95.7)$, Trachyrynchus murrayi $(\mathrm{IV}=70.0)$ and Lepidion eques $(\mathrm{IV}=25.7)$. Reinhardtius hippoglossoides also has its highest indicator value for a single assemblage in this assemblage (Fig 3, Table 1) but the highest indicator value is found in Assemblage 4 and 5 combined (Appendix 2).

Assemblage 5 is the second deepest assemblage but found at statistically significant $(95 \%$ level) shallower depth (mean $835 \mathrm{~m}$ ) and temperature $\left(2.4^{\circ} \mathrm{C}\right)$ than Assemblage 4 (Fig 4, Table 1). The assemblage has no indicator species but Notacanthus chemnitzii, Macrourus berglax and Bathyraja spinicauda have their highest indicator value for a single assemblage here but all three species are indicator species for Assemblage 4 and 5 combined (Appendix 2). Assemblage 5 is separated from Assemblage 4 by the absence of Antimora rostrata and Trachyrynchus murrayi and very few Coryphaenoides rupestris, Synaphobranchus kaupi, Lepidion eques and Reinhardtius hippoglossoides.

Assemblage 6 is found at mean depth of $404 \mathrm{~m}$ and mean temperature of $4.5^{\circ} \mathrm{C}$. Molva dipterygia $(\mathrm{IV}=50.3)$ is the primary indicator species and Sebastes mentella has by far its highest indicator value for a single assemblage here $(I V=90.0)$ although it is indicator species for Assemblage 6 and 7 combined (Appendix 2). The secondary indicator species Brosme brosme has also it highest indicator value for a single assemblage here (Fig 4, Table 1).

Assemblage 7 is the third deepest assemblage with a mean depth of $600 \mathrm{~m}$ and a mean temperature of $3.6^{\circ} \mathrm{C}$. The depth is significantly different $(95 \%$ level) from the deeper Assemblage 5 and the shallower Assemblage 6, while the temperature difference between the shallower and deeper assemblages is barely statistically different (95\% level) (Table 1). The only primary indicator species is Amblyraja radiata (IV=24.2) (Fig.5, Table 1). The Assemblage is separated from the deeper Assemblage 5 primarily by the presence of Amblyraja radiata and the absence of Notacanthus chemnitzii and Macrourus berglax and from 


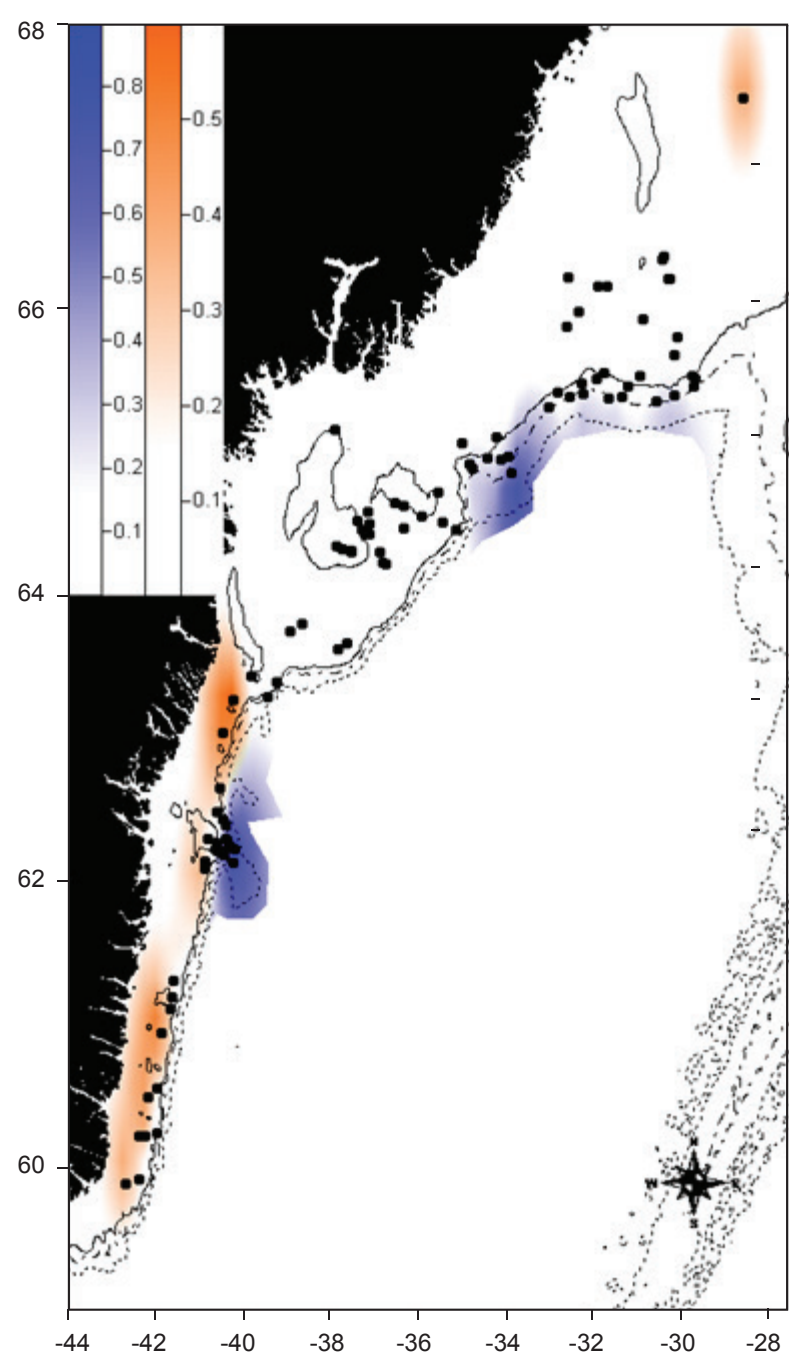

Fig 3. Southern area. Iso-probability map representing the spatial distribution of the possibility of belonging to Assemblages 4 and 8. Assemblage 4: ) and 8: ). Note difference in the scale. Depth contours: $500 \mathrm{~m}$ solid, $1000 \mathrm{~m}$ dashed, $1500 \mathrm{~m}$ dotted.

the shallower Assemblage 6 by low indicator values of Molva dipterygia and Sebastes mentella.

Assemblage 8 is the shallowest located assemblage with a mean depth of $190 \mathrm{~m}$ and mean temperature of $4.4^{\circ} \mathrm{C}$ (Table 1). The assemblage is primarily located in the southern part of the survey area but single haul north of Dohrn Bank is also associated Assemblage 8 (Fig. 3). Gadus morhua is the only indicator species (IV=73.8) and the assemblage is characterized by relatively few species with low indictor levels. The depth is significantly different from the slightly deeper Assemblage 9 from which it is separated mainly because of strong presence of Gadus morhua and few Melanogrammus aeglefinus and Sebastes marinus (Table 1).

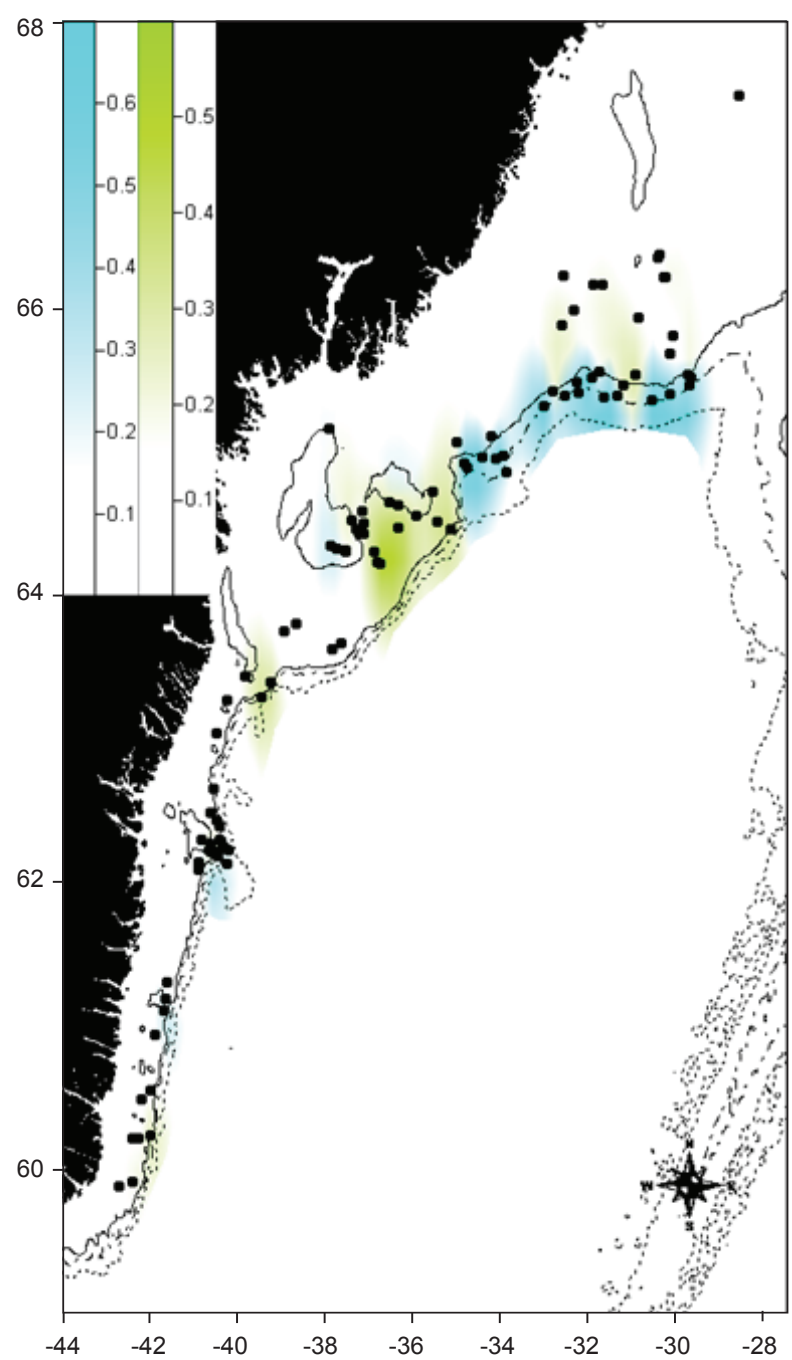

Fig 4. Southern area. Iso-probability map representing the spatial distribution of the possibility of belonging to Assemblages 5 and 6. Assemblage: 5 ) and 6: ). Note difference in the scale. Depth contours: $500 \mathrm{~m}$ solid, $1000 \mathrm{~m}$ dashed, $1500 \mathrm{~m}$ dotted.

Assemblage 9 is found all along the coast (Fig. 5) and has a mean depth of $312 \mathrm{~m}$ and a mean temperature of $4.1{ }^{\circ} \mathrm{C}$ (Table 2). Sebastes marinus is the only primary indicator species (IV=64.8) but Anarhichas lupus, Melanogrammus aeglefinus and Hippoglossoides platessoides have their highest indicator values for a single assemblage in this assemblage. The assemblages mean depth is significantly different (95\%) from the shallower Assemblage 8 and the deeper Assemblage 6, while there is no statistical difference in mean temperature between the assemblages. Assemblage 9 is separated from Assemblage 6 by the high presence of Sebastes marinus, Melanogrammus aeglefinus and Anarhichas lupus in Assemblage 9 and high presence of Molva dipterygia and Sebastes mentella in Assemblage 6 while these species are rare in Assemblage 9. 


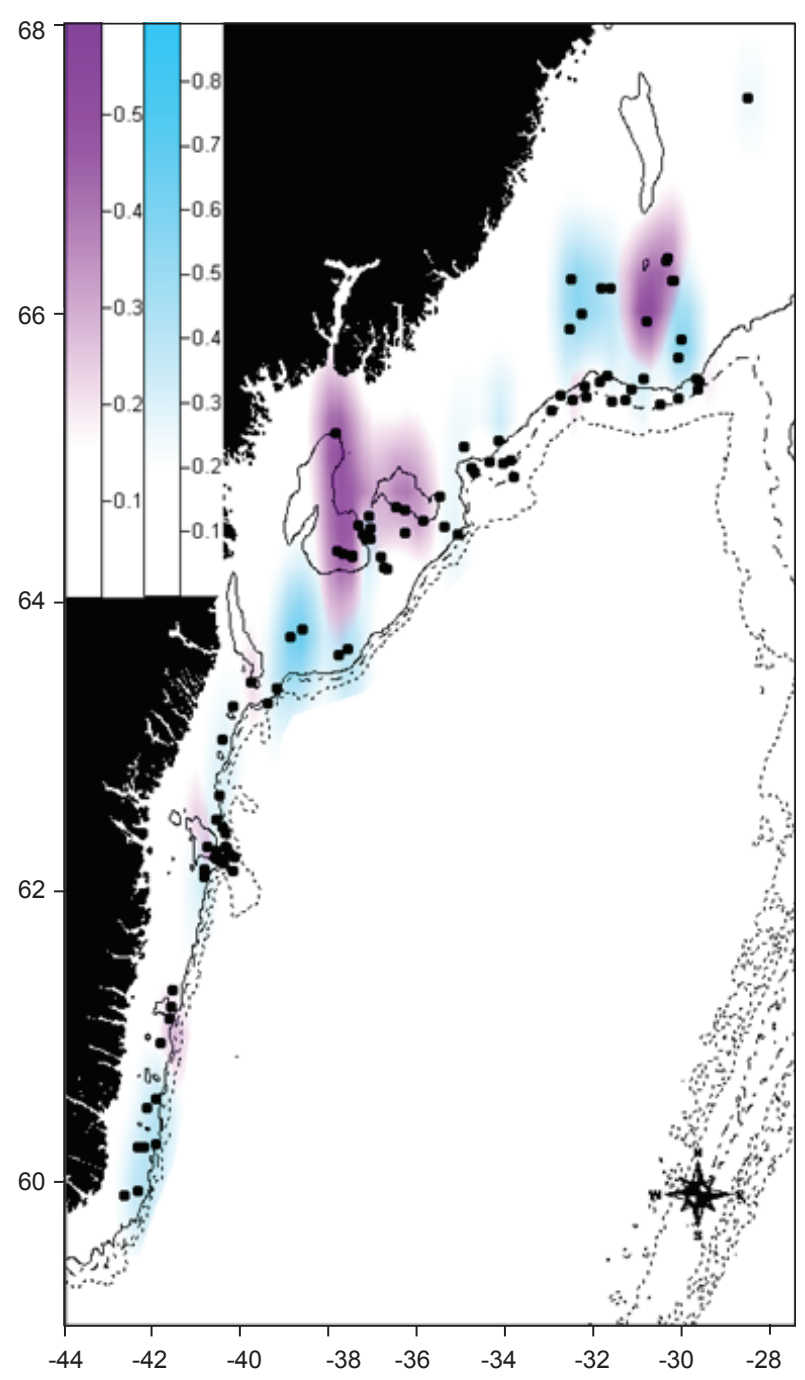

Fig 5. Southern Area. Iso-probability map representing the spatial distribution of the possibility of belonging to Assemblages 7 and 9. Assemblage 7: ) and 9: ). Note difference in the scale. Depth contours: $500 \mathrm{~m}$ solid, $1000 \mathrm{~m}$ dashed, $1500 \mathrm{~m}$ dotted.

A number of indicator species cannot be grouped within a particular assemblage but are more or less widespread throughout a number of assemblages. Amblyraja hyperborea $(\mathrm{IV}=62.4)$ is primary indicator species for the three Assemblages (1-3) in the Iceland Sea, while Careproctus reinhardti (IV=33.3), Lycodes seminudus (IV=12.2), L. eudipleurostictus (IV=21.2) and L. pallidus $(\mathrm{IV}=15.5)$ are secondary indicator species for the same area (Appendix 2). Macrourus berglax ( $\mathrm{IV}=91.3)$, Reinhardtius hippoglossoides (IV=76.6) and Centroscyllium fabricii $(\mathrm{IV}=40.5)$ are primary indicator species and Bathyraja spinicauda $(\mathrm{IV}=30.3)$ is secondary indicator species for the deepest part of the survey area in the Irminger Sea (Assemblage 4 and 5), while Hippoglossoides plattessoides (IV=45.4) is generalist (eurytrophic) found widespread in the shallower Assemblages (6-9). Some species as Sebastes mentella $(\mathrm{IV}=96.4)$ and Amblyraja fyllae (IV=44.1) are assigned to intermediated depths (Assemblage 6 and 7) while others as Anarhichas lupus $(\mathrm{IV}=46.2)$, Melanogrammus aeglefinus $(\mathrm{IV}=51.1)$ and Triglops murrayi $(\mathrm{IV}=17.6)$ are primarily found at shallow depths (Assemblage 8 and 9) (Table 2, Appendix 2).

The relative probability of finding one of the 25 primary species within one of the nine assemblages is provided in Table 2 (Jørgensen et al., 2005). Reinhardtius hippoglossoides is found in eight out of nine assemblages and there is a relatively high probability of finding it in five out of the nine assemblages. The species has it highest probabilities in Assemblage 2 and 3 in the Iceland Sea, but the indicator value is relatively low (Table 1). This is caused by hauls with few species in low numbers. It should be noticed that abundance differences among assemblages are not included in these probabilities and the probabilities (or relative abundance) can only be used for direct comparison within assemblages. A species like Sebastes mentella is also found in a number of assemblages, but with the highest probability (0.60, 0.43) in Assemblage 6 and 7, respectively (medium deep water in the Irminger Sea, Table 2). Other species are only found within a few assemblage e.g., Antimora rostrata and Centrocyllium fabricii, which are only found in the two deepest Assemblages in the Irminger Sea (Ass. 4 and 5) and Trachyrhynchus murrayi which is exclusively found in Assemblage 4 (Table 2).

\section{Discussion}

\section{Methods}

The analyses are based on data from 2006 (northern area) and 2008 (southern area) (Fig. 1). Most of the species included in the analyses are long lived (Whitehead et al., 1984), and fishing pressure has been low north of Dohrn Bank from 2006 to 2008 (Anon., 2009). Further it is assumed that the bottom temperature in the northern area has been stable between 2006 and 2008 as in the southern area (Pers. Com. Kaj Sünksen, Greenland Institute of Natural Resources. Unpublished survey results). It is hence considered that the changes in species composition and abundance in the northern area between 2006 and 2008 has been insignificant.

In 2008 there were used two different survey trawls with 20 and $30 \mathrm{~mm}$ mesh in the codend, respectively. There was a certain overlap in the depths were the two trawls 
Table 2. Estimated relative abundance of primary indicator species within the nine assemblages.

\begin{tabular}{|c|c|c|c|c|c|c|c|c|c|}
\hline \multirow[t]{2}{*}{ Species } & \multicolumn{9}{|c|}{ Assemblage } \\
\hline & 1 & 2 & 3 & 4 & 5 & 6 & 7 & 8 & 9 \\
\hline Centroscyllium fabricii & 0.000 & 0.000 & 0.000 & 0.046 & 0.032 & 0.000 & 0.005 & 0.000 & 0.000 \\
\hline Amblyraja fyllae & 0.000 & 0.000 & 0.000 & 0.004 & 0.014 & 0.035 & 0.064 & 0.000 & 0.000 \\
\hline Amblyraja hyperborea & 0.365 & 0.066 & 0.120 & 0.004 & 0.000 & 0.000 & 0.000 & 0.000 & 0.000 \\
\hline Amblyraja radiata & 0.000 & 0.038 & 0.049 & 0.004 & 0.021 & 0.009 & 0.099 & 0.000 & 0.006 \\
\hline Synaphobranchus kaupi & 0.000 & 0.000 & 0.001 & 0.128 & 0.034 & 0.000 & 0.003 & 0.000 & 0.000 \\
\hline Notacanthus chemnitzii & 0.000 & 0.000 & 0.001 & 0.031 & 0.095 & 0.000 & 0.000 & 0.000 & 0.000 \\
\hline Trachyrhynchus murrayi & 0.000 & 0.000 & 0.000 & 0.076 & 0.000 & 0.000 & 0.000 & 0.000 & 0.000 \\
\hline Coryphaenoides rupestris & 0.000 & 0.000 & 0.001 & 0.176 & 0.039 & 0.003 & 0.000 & 0.000 & 0.000 \\
\hline Macrourus berglax & 0.006 & 0.004 & 0.118 & 0.144 & 0.290 & 0.023 & 0.086 & 0.000 & 0.022 \\
\hline Gadus morhua & 0.000 & 0.000 & 0.019 & 0.000 & 0.000 & 0.083 & 0.005 & 0.543 & 0.157 \\
\hline Melanogrammus aeglefinus & 0.000 & 0.000 & 0.001 & 0.000 & 0.000 & 0.000 & 0.005 & 0.109 & 0.067 \\
\hline Gaidropsarus argentatus & 0.525 & 0.007 & 0.125 & 0.010 & 0.067 & 0.007 & 0.010 & 0.004 & 0.002 \\
\hline Molva diterygia & 0.000 & 0.000 & 0.000 & 0.016 & 0.019 & 0.099 & 0.029 & 0.000 & 0.009 \\
\hline Antimora rostrata & 0.000 & 0.000 & 0.000 & 0.112 & 0.005 & 0.000 & 0.000 & 0.000 & 0.000 \\
\hline Lepidion eques & 0.000 & 0.000 & 0.000 & 0.040 & 0.014 & 0.000 & 0.010 & 0.000 & 0.000 \\
\hline Anarhichas lupus & 0.000 & 0.000 & 0.001 & 0.000 & 0.000 & 0.017 & 0.000 & 0.059 & 0.073 \\
\hline Sebastes mentella & 0.000 & 0.000 & 0.000 & 0.010 & 0.177 & 0.599 & 0.436 & 0.000 & 0.242 \\
\hline Sebastes marinus & 0.000 & 0.000 & 0.001 & 0.013 & 0.018 & 0.067 & 0.004 & 0.098 & 0.262 \\
\hline Artediellus atlanticus & 0.000 & 0.123 & 0.052 & 0.000 & 0.000 & 0.000 & 0.000 & 0.004 & 0.002 \\
\hline Triglops murrayi & 0.000 & 0.001 & 0.000 & 0.000 & 0.000 & 0.004 & 0.002 & 0.057 & 0.009 \\
\hline Triglops nybelini & 0.000 & 0.249 & 0.000 & 0.000 & 0.000 & 0.000 & 0.000 & 0.004 & 0.001 \\
\hline Cottunculus microps & 0.031 & 0.060 & 0.232 & 0.000 & 0.004 & 0.005 & 0.010 & 0.000 & 0.001 \\
\hline Liparis fabricii & 0.044 & 0.212 & 0.000 & 0.000 & 0.000 & 0.000 & 0.000 & 0.000 & 0.000 \\
\hline Hippoglossoides platessoides & 0.000 & 0.016 & 0.000 & 0.000 & 0.000 & 0.034 & 0.023 & 0.121 & 0.121 \\
\hline Reinhardtius hippoglossoides & 0.028 & 0.223 & 0.276 & 0.185 & 0.168 & 0.013 & 0.209 & 0.000 & 0.027 \\
\hline
\end{tabular}

Note. Values give the estimated probabilities of a a randomly drawn specimen from the assemblage belonging to each of the 25 species i.e., the probability vectors characterizing the assemblage.

where used (400-600 m) but there were too few hauls and they were located too far from each other to allow a firm conclusion about the difference in selectivity in the two gears. Bech (1994) compared the selectivity in codends on 20 and $44 \mathrm{~mm}$, respectively, in West Greenland waters. There was no difference in selectivity for Reinhardtius hippoglossoides but there was a significant difference in selectivity for small redfish. The catchability for $10 \mathrm{~cm}$ redfish in a $20 \mathrm{~mm}$ cod end was 2.9 times higher than in a $44 \mathrm{~mm}$ cod end (no data for $11 \mathrm{~cm}$ redfish indicating that there was no difference in catchability in the two mesh sizes at that size). For comparison it is assumed that (red)fish $>9 \mathrm{~cm}$ are fully recruited to the $30 \mathrm{~mm}$ trawl. Fish less than $10 \mathrm{~cm}$ contributed $0.2 \%$ of the catches in numbers at depths between 400 and $600 \mathrm{~m}$ in the $30 \mathrm{~mm}$ codend compared to $5.7 \%$ of the catches with the $20 \mathrm{~mm}$ codend. (62\% of the catches were small redfish from a single haul). The trawl with the $20 \mathrm{~mm}$ codend covered depths shallower than $600 \mathrm{~m}$ where only $4.2 \%$ of the caches were $<10 \mathrm{~cm}$ and $92.6 \%$ of these small fish were Sebastes mentella. The abundance of $S$. mentella seems hence to be slightly overestimated in the $20 \mathrm{~mm}$ trawl compared to the $30 \mathrm{~mm}$ trawl but the difference in mesh size only have a very minor effect on the abundance estimates on other species. The overall distribution of $S$. mentella is probably not affected by the difference in mesh size while the relative distribution of indicator value between Assemblage 6 (mainly covered by the $20 \mathrm{~mm}$ trawl) and Assemblage 7 (mainly covered by the $30 \mathrm{~mm}$ trawl) could be twisted slightly. 
The bottom topography with either very rough and steep or very soft and muddy bottom that not allow bottom trawling, together with areas at the coast that not has been surveyed due to incomplete maps implies that there are areas with no information. This applies to the entire costal area and a rather large area with relatively shallow water between $64^{\circ} \mathrm{N}$ and $68^{\circ} \mathrm{N}$ and areas $>1000$ $\mathrm{m}$ between $62^{\circ} 45^{\prime} \mathrm{N}$ and $64^{\circ} \mathrm{N}$ together with depths $>600$ $\mathrm{m}$ south of $61^{\circ} 45^{\prime} \mathrm{N}$. This results in incomplete distribution maps. This applies especially to Assemblage 4 (Fig. 3) but also Assemblage 5 (Fig 4). These two assemblages are composed of species found wide spread in the North Atlantic such as Antimora rostrat, Coryphaenoides rupestris, Synaphobranchus kaupi, Trachyrhynchus murrayi, Centrocyllium fabricii, Notacanthus chemnizii and Macrourus berglax (Whitehead et al., 1984-1986) and there is no reason to believe that these species should not be distributed all along the slope of the Irminger Sea.

For a discussion of the Bayesian multinomial logit model see Jørgensen et al. (2005)

\section{Results}

The study shows that three of the identified assemblages are located north of Dohn Bank in the cold water in the Iceland Sea while six are located in the relatively warm Irminger Sea. The bottom fish fauna in Iceland Sea is hence to a large extend separated from the fish fauna in the Irminger Sea by the submarine sill between Iceland and East Greenland (Dohrn Bank) and there is little overlap in the species composition in the two areas. A similar separation between areas has also been shown for some fish families e.g., Macroridae (Jørgensen 1996) and Zoarcidae (Møller and Jørgensen, 2000), and for the total fish fauna at West Greenland (Jørgensen et al., 2005).

One station from Assemblage 8, which is mainly found in the Irminger Sea, is, however, located in the Iceland Sea. This haul is associated to Assemblage 8 due to the presence of Gadus morhua and Hippoglossoides platessoides and general absence of species found in the three Iceland Sea assemblages. The station was the shallowest in the northern area $(288 \mathrm{~m})$ with a bottom temperature among the highest $\left(1.4^{\circ} \mathrm{C}\right)$.

Haedrich and Krefft (1978) identified five assemblages in the Irminger Sea, Denmark Strait and Icelandic Sea based on 27 trawl hauls of which eight were located at the Icelandic slope, where the bottom temperatures generally were higher than at East Greenland. They also included pelagic species and generally the range in temperature and depth in the assemblages was much wider in their study which further complicates a direct comparison with the present study. Haedrich and Krefft (1978) identified an assemblage in the Iceland Sea (three hauls at 330-693 m, $-0.7-0.5^{\circ} \mathrm{C}$ ) dominated by Reinhardtius hippoglossoides which also is relatively important in Assemblage 3 in the present study. Their second most important species Gadus morhua was only observed in a single haul in the Icelandic Sea in 2006 but it is likely that this assemblage would have been more widespread north of the sill if the coverage of the shallow areas had been better.

A few other species as the highly migratory Reinhardtius hippoglossoides and species such as Amblyraja radiata and Gaidropsarus argentatus found widespread north and south of the sill indicating that they tolerate a wide range of temperatures including temperatures close to $0^{\circ} \mathrm{C}$.

\section{Iceland Sea}

In the Iceland Sea the three assemblages (1,2 and 3$)$ were different regarding mean temperature, mean depth and species composition. Assemblage 2 and 3 were however not significantly different (95\% level) neither regarding temperature nor depths indicating that factors other than these two parameters e.g. bottom conditions, salinity, current strength etc. determines the distribution of the fish. The lack of statistical difference could also be caused by the relatively few observations in Assemblage 3.

It is generally difficult to compare fish assemblages from different areas, since they have usually been defined by different sampling gear and calculation methods. Jørgensen et al. (2005, 2011) identified, however, a number fish assemblage in the Baffin Bay and Davis Strait using same approach as presented here.

The shallowest assemblage (Ass. 2) with the indicator species Liparis fabricii, Triglops nybelini and Leptagonus decagonus, and with a large presence of Artediellus atlanticus, resembles an assemblage in the Northern Baffin Bay with a mean depth at $459 \mathrm{~m}$ and mean temperature on $0.4^{\circ} \mathrm{C}$ where the three species also were indicator species, while Liparis fabricii was found widespread in cold the northern Baffin Bay (Jørgensen et al., 2011).

The assemblage at intermediate depth (Ass. 3) has Cottunculus microps as indicator species. The species was also common at a similar depth $(652 \mathrm{~m})$ in the northern Baffin Bay together with Careproctus reinhardti and Lycodes seminudus which also are common in the Iceland Sea (Jørgensen et al., 2011).

The deepest assemblage in the Iceland Sea (Ass.1) has Gaidropsarus argentatus as primary indicator species and Lycodes squamiventer, Paraliparis bathybius and 
Rhodichthys regina as secondary indicator species. Gaidropsarus argentatus is also found in the southern area but not in the Baffin Bay, where it is replaced by G. ensis. Paraliparis bathybius and Rhodichthys regina were indicator species for assemblages at similar depths (app. $1100 \mathrm{~m}$ ) in both the northern and southern part of the Baffin Bay. Amblyraja hyperborea that is found widespread in the Iceland Sea is also found widespread in the Northern Baffin Bay (Jørgensen et al., 2011) and is primary indicator species in the deepest assemblage in the southern Baffin Bay (Jørgensen et al., 2005). Amblyraja hyperborea was also one of the dominating species in the "upper slope (cold) assemblage" defined by Bergstad et al. (1999). All in all the species composition especially in the northern Baffin Bay but also to a wide extend in the southern Baffin Bay resembles the species composition in the Greenland part of the Iceland Sea. In the shallower part of southern Baffin Bay there is, however, some southern distributed species brought to the area by the warm West Greenland Current (Jørgensen et al., 2005). Assemblage 1 in the Iceland Sea have also considerable resemblance to the cold Arctic "Norwegian Sea Deep-water assemblage", depths ranging from 1498-2051 m, defined by Bergstad et al. (1999) from the slope of the eastern Norwegian Sea. The latter was dominated by Lycodes frigidus, of which only a few specimens were taken at negative temperature in the Iceland Sea and the two Liparids, Paraliparis bathybius and Rhodichthys regina, which are secondary indicator species in Assemblage 1.

\section{Irminger Sea}

In the Irminger Sea six different assemblages were identified, all at significantly (95\% level) different depth. The temperature was, however, relatively uniform throughout the area and only Assemblage 5 was significantly colder than the two closest assemblages, Assemblage 4 and 7.

The medium depth Assemblages 6 and 7 (mean depths 404 and $600 \mathrm{~m}$, respectively) resembles a similar assemblage $\left(3.5^{\circ} \mathrm{C}\right.$ and mean depth $\left.525 \mathrm{~m}\right)$ in the Davis Strait and southern Baffin Bay where Sebastes mentella and Hippoglossoides platessoides are primary indicator species. Sebastes mentella is primary indicator species in Assemblage 6-7 while Hippoglossoides platessoides is found widespread in the four shallow assemblages in the Irminger Sea. The study in the Davis Strait did not cover depths $<400 \mathrm{~m}$.

The deepest assemblage in the Irminger sea resembles a similar assemblage $\left(3.6^{\circ} \mathrm{C}\right.$ and mean depth $\left.1104 \mathrm{~m}\right)$ in the Davis Strait where Antimora rostrata, Coryphaenoides rupestris, Synaphobranchus kaupi and Centrocyllium fabricii, that are found widespread in the North Atlantic, also were indicator species (Jørgensen et al., 2005).

Rätz (1999) analysed the structures and changes of demersal fish assemblage off West and East Greenland at depths between 0 and $400 \mathrm{~m}$ during 1982-1996. The most abundant species were Sebastes marinus, Sebastes mentella, Gadus morhua, Hippoglossoides platesoides, Anarhichas lupus and Amblyraja radiata, which also are common in the shallow Assemblages 6, 8 and 9 in the present study. Rätz focused on abundance, biomass and mean weights and it is hard to make any further comparisons with the present study regarding changes in the composition of demersal fish assemblages in the intervening years.

Haedrich and Krefft (1978) identified an assemblage (493-975 $\mathrm{m}, 0.1-3^{\circ} \mathrm{C}$ ) resembling Assemblage 5 in temperature and depth where Macrourous berglax, Coryphaenoides rupestris, Antimora rostrata and Gaidropsarus argentatus where the most dominant species. Assemblage 5 is to a large extend defined by the absence of a large number of species and the species Haedrich and Krefft mention are dominant species in the deep Assemblage 4 while Gaidropsarus argentatus is dominant species in the cold deep Assemblage 1 and rare in the Irminger Sea. Haedrich and Krefft also defined an assemblage $\left(763-1502 \mathrm{~m}, 3.9-5.6^{\circ} \mathrm{C}\right)$ resembling Assemblage 4 which included Coryphaenoides rupestris and Lepidion eques that also are dominant species in Assemblage 4. Further their assemblage included Sebastes mentella which not is present in Assemblage 4. Whether the general deeper distribution of some species (Macrourous berglax and Antimora rostrata) more northern (Gaidropsarus argentatus), more southern (Gadus morhua) or shallower (Sebastes mentella) distribution in the present investigations compared to the distributions described by Haedrich and Krefft (1978) are caused by changes in the environment or due to the relatively few observations in their study is not clear.

In their investigation of the fish assemblages off eastern Canada and USA Mahon et al. (1998) defined a "Northern Deep Water assemblage" which had the species Antimora rostrata, Coryphaenoides rupestris, Synaphobranchus kaupi, Notacanthus chemnitzi and Macrourus berglax in common with the two deepest assemblages in the Irminger Sea (Assemblage 4-5). These species are widely distributed in the North Atlantic (Whitehead et al., 1984-1986), but it is worth noting that the mean depth was $537 \mathrm{~m}$ (however with a large variance) with a mean temperature of $4.1^{\circ} \mathrm{C}$ in Mahon et al. (1998) compared to a mean depth of $1110 \mathrm{~m}$ and $3.9^{\circ} \mathrm{C}$ in the present 
investigation. This suggests a shift to deeper waters in far northern areas for these species that may be related to temperature preferences.

The present study confirms that depth and oceanographic features (mainly temperature) is the most important factors in separating fish assemblages in the North Atlantic and World-wide (Gomes et al., 1995). The equal importance of depth and temperature at East Greenland is in accordance with Haedrich and Krefft (1978) who suggested that the slope fish fauna of the temperature-unstable Denmark Strait is structured by both depth and temperature. At the even more temperature extreme Norwegian shelf, major importance of temperature as the separating factor of fish assemblages was hypothesized by Bergstad et al., (1999) and Bjelland et al., (2000). The major importance of depth and minor contribution of temperature in defining the distribution patterns at both East and West Greenland is in accordance with studies from other areas with limited temperature gradients e.g. New England (Haedrich et al. ,1975) and Rockall Trough (Gordon and Duncan 1985). At East Greenland temperature only had a significant influence on the distribution of the fish between the cold Iceland Sea and the warm Irminger Sea. Within the areas depth seem to be the most dominating parameter regarding the distribution of the fish fauna.

\section{Acknowledgement}

The authors express their thanks to two reviewers for constructive comments and suggestions that helped improve the final version of the manuscript.

\section{References}

ANON. 2009. ICES Northwestern Working group report.

BECH, G. 1994. Biomass and Abundance of Greenland halibut (Reinhardtius hippoglossoides) and redfish (Sebastes sp.) from a bottom Trawl Survey in NAFO Subarea 1 in 1993. NAFO SCR Doc. 94/9.

BERGSTAD, O. A., O. BJELLAND and J. D. M.GORDON, 1999. Fish communities on the slope of the eastern Norwegian Sea. Sarsia, 84: 67-78.

BJELLAND, O., O. A. BERGSTAD, J. E. SKJÆRÅSEN and K. MELAND. 2000. Trophic ecology of deep-water fishes associated with the continental slope of the eastern Norwegian Sea. Sarsia, 85: 101-117. http://dx.doi.org/10. 1080/00364827.2000.10414561

BUCH, E. MS. 2000. A monograph on the physical oceanography of the Greenland waters. Danish Metrological Institute. Scientific Report 00-12. 405 pp.

CHRISTIANSEN, J. S., J. D. REIST, R. J. BROWN, V. A. BRYKOV, G. CHRISTENSEN, K. CHRISTOFFERSEN, P. COTT, P. CRANE, J. B. DEMPSON, M. DOCKER, K. DUNMALL,A. FINSTAD, V.F. GALLUCCI, J. HAMMAR,
L. N. HARRIS, J. HEINO, E. VANOV, O. V. KARAMUSHKO, A. KIRILLOV, A. KUCHERYAVYY, H. LEHTONEN, A. LYNGHAMMAR, C. W. MECKLENBURG, P. D. R. MØLLER, T. MUSTONEN, A. G. OLEINIK, M. POWER, Y. S. RESHETNIKOV, V. I. ROMANOV, O-T. SANDLUND, C. D. SAWATZKY, M. SVENNING, H. K. SWANSON, and F. J. WRONA. 2013. Fishes (Chapter 6). In: Arctic Biodiversity Assessment. Status and trends in Arctic biodiversity. H. Meltofte (ed.), Conservation of Arctic Flora and Fauna, Akureyri, p. 192-245.

CONGDON, P. 2001. Bayesian statistical modelling. Wiley, London. 556 pp.

DUFRÊNE, M. and P. LEGENDRE, 1997. Species assemblages and indicator species. Ecological Monographs: 67(3), 345-366.

GOMES, M. C., R. L. HAEDRICH, and M. G. VILLAGARCIA, 1995. Spatial and temporal changes in the groundfish assemblages on the north-east Newfoundland/Labrador Shelf, north-west Atlantic, 1978-1991. Fisheries Oceanography, 4: 85-101. http://dx.doi.org/10.1111/j.1365-2419.1995. tb00065.x

HAEDRICH, R. L., G. T. ROWE, and P. T. POLLONI, 1975. Zonation and faunal composition of epibenthic populations on the continental slope south of New England. Journal of Marine Research, 33(2): 191-212.

HAEDRICH, R. L. and G. KREFFT, 1978. Distribution of bottom fishes in the Denmark Strait and Irminger Sea. DeepSea Research, 25: 705-720. http://dx.doi.org/10.1016/01466291(78)90625-2

JØRGENSEN, O. A. 1996. Distribution and Biology of Grenadiers (Macrouidae) in West Greenland Waters. $J$. Northwest Atlantic Fisheries Science, 18: 7-29. http:// dx.doi.org/10.2960/J.v18.a1

JØRGENSEN, O. A., C. HVINGEL, P. R. MØLLER and M.A. TREBLE, 2005. Identification and mapping of bottom fish assemblages in Davis Strait and Southern Baffin Bay. Canadian Journal of Fisheries and Aquatic Science, 62: http://dx.doi.org/10.1139/f05-101

JØRGENSEN, O. A., C. HVINGEL and M. A. TREBLE, 2011. Identification and mapping of bottom fish assemblages in Northern Baffin Bay. Journal of Northwest Atlantic Fishery Science, 43: 65-78. http://dx.doi.org/10.2960/J.v43.m666

KINGSLEY, M. C. S., P. KANNEWORFF, and D. CARLSSON, M. 2004. Buffered random sampling: a sequential inhibited spatial point process applied to sampling in trawl survey for northern shrimp Pandalus borealis in West Greenland waters. ICES Journal of Marine Science. 61:12-24. http:// dx.doi.org/10.1016/j.icesjms.2003.11.001

LEGENDRE P. and L. LEGENDRE, 1998. Numerical etologi. Amsterda. Elsevier. 853 pp.

MAHON, R., S. K. BROWN, K. C. T. ZWANENBURG, D. B. ATKINSON, K. R. BUJA, L. CLAFLIN, G. D. HOWELL, M. E. MONACO, R. N. O'BOYLE and M. SINCLAIR, 1998. Assemblages and biogeography of demersal fishes of the east coast of North America. Canadian Journal of Fisheries and Aquatic Science, 55: 1704-1738. http:// dx.doi.org/10.1139/f98-065 
MATHERON, G. 1962. Traités de Géostatistiques Appliquée. Paris: Editions technic.

MECKLENBURG, C. W., P. R. MØLLER and D. STEINKE, 2011. Biodiversity of arctic marine fishes: taxonomy and zoogeography, Arctic Ocean Diversity Synthesis. Marine Biodiversity, 41: 109-140. http://dx.doi.org/10.1007/ S12526-010-0070-Z

MØLLER P. R. and O. A. JØRGENSEN, 2000. Distribution and abundance of eelpouts (Pisces, Zoarcidae) off West Greenland. Sarsia, 85: 23-48. http://dx.doi.org/10.1080/0 0364827.2000 .10414553

MØLlER, P. R., J. G. NIELSEN, S.W. KNUDSEN, J.Y. POULSEN, K. SÜNKSEN, and O. A. JØRGENSEN, 2010. Zootaxa A checklist of the fish fauna of Greenland waters, Zootaxa 2378: 1-84.

PRIMER. 2001. Primer software for Windows v. 5.2. PRIMER-E
Ltd. 6 Hedingham Gardens. Roborough. Plymouth. PL6 7DX, United Kingdom.

RÄTZ H.-J. 1999. Structures and Changes of Demersal Fish Assemblage off Greenland, 1982-96. NAFO Scientific Council Studies, 32: 1-15.

SOUISSI, S., F. IBANEZ, R. B. HAMADOU, J. BOUCHER, A. C. CATHELINEAU, F. BLANCHARD and J.-C. POULARD, 2001. A new multivariate mapping method for studying species assemblages and their habitats: example using bottom trawl surveys in the Bay of Biscay (France). Sarsia, 86: 527-542. http://dx.doi.org/10.1080/00364827 .2001 .10420491

WHITEHEAD, P. J. P., M.-L. BAUCHOT, J.-C. HUREAU, J. NIELSEN, and E. TORTONESE, (Eds). 1984-1986. Fishes of the North-eastern Atlantic and the Mediterranean. UNESCO, Paris.

\section{Appendix 1.}

Species list from two surveys at East Greenland in 2006 and 2008, respectively. Status:"p" considered pelagic. Number: Maximum number caught in a single haul. Depth: Minimum and Maximum depth (m). Temperature; Minimum and maximum temperature ${ }^{\circ} \mathrm{C}$. and maximum northern latitude.

\begin{tabular}{|c|c|c|c|c|c|c|c|}
\hline \multirow[b]{2}{*}{ Species } & \multirow[b]{2}{*}{ Status } & \multirow[b]{2}{*}{ Number } & \multicolumn{2}{|c|}{ Depth } & \multicolumn{2}{|c|}{ Temperature } & \multirow{2}{*}{$\begin{array}{l}\text { Northern } \\
\text { Latitude }\end{array}$} \\
\hline & & & Min & Max & Min & Max & \\
\hline Petromyzon marinus (Sea lamprey) & & 3 & 459 & 759 & 1.9 & 5.4 & 65.532 \\
\hline Myxine glutinosa (Hagfish) & & 3 & 417 & 494 & 4.0 & 5.2 & 64.527 \\
\hline Centroscyllium fabricii (Black dogfish) & & 43 & 631 & 1281 & 2.9 & 5.2 & 64.972 \\
\hline Somniosus microcephalus (Greenland shark) & & 1 & 692 & 692 & 4.1 & 4.1 & 65.161 \\
\hline Bathyraja spinicauda (Spinetail ray) & & 4 & 328 & 1026 & 0.5 & 5.0 & 65.513 \\
\hline Amblyraja hyperborea (Arctic skate) & & 14 & 312 & 1460 & -0.6 & 3.4 & 71.612 \\
\hline Amblyraja radiate (Starry skate) & & 20 & 291 & 906 & 0.1 & 5.1 & 70.597 \\
\hline Amblyraja fyllae (Round ray) & & 7 & 328 & 910 & 1.1 & 5.3 & 66.212 \\
\hline Rajella bathyphila (Deepwater ray) & & 2 & 869 & 1460 & 1.1 & 3.4 & 65.392 \\
\hline Alepocephalus agassizzi (Agassiz slickhead) & & 32 & 897 & 1460 & 3.0 & 4.4 & 64.861 \\
\hline Alepocephalus bairdii (Baird's smooth-head) & & 3 & 675 & 1265 & 3.9 & 5.1 & 62.198 \\
\hline Bajacalifornia megalops (Big-eye mooth-head) & & 1 & 391 & 873 & 0.5 & 3.2 & 65.536 \\
\hline Rouleina maderensis (Maderian smooth-head) & $\mathrm{p}$ & 2 & 890 & 890 & 4.9 & 4.9 & 62.392 \\
\hline Xenodermichthys copei (Bluntsnout smooth-head) & $\mathrm{p}$ & 2 & 316 & 1257 & 2.2 & 5.6 & 65.536 \\
\hline Holtbyrnia anomala (Bighead serasid) & $\mathrm{p}$ & 2 & 391 & 391 & 3.2 & 3.2 & 65.536 \\
\hline Maulisia mauli (Maul's searasid) & $\mathrm{p}$ & 1 & 1060 & 1060 & 2.5 & 2.5 & 65.414 \\
\hline Maulisia microlepis (Smallscale serasid) & $\mathrm{p}$ & 2 & 1252 & 1460 & 3.1 & 3.4 & 62.224 \\
\hline Normichthys operosus (Multipore searsid) & & 1 & 1072 & 1072 & 3.0 & 3.0 & 64.861 \\
\hline $\begin{array}{l}\text { Sagamichthys schnakenbecki (Schnakenbeck's } \\
\text { searsid) }\end{array}$ & $\mathrm{p}$ & 1 & 391 & 391 & 3.2 & 3.2 & 65.536 \\
\hline Cyclothone microdon (Veiled anglemouth) & $\mathrm{p}$ & 37 & 316 & 1072 & 0.8 & 5.6 & 66.353 \\
\hline Polyipnus polli (Poll's hatchetfish) & $\mathrm{p}$ & 2 & 316 & 444 & 5.0 & 5.6 & 62.436 \\
\hline Borostomias antarcticus (Snaggletooth) & $\mathrm{p}$ & 5 & 391 & 1460 & 2.4 & 4.0 & 65.551 \\
\hline
\end{tabular}


Chauliodus sloani (Sloane's viperfish)

Stomias boa (Boa dragonfish)

Trigonolampa miriceps (Threelight dragonfish)

Malacosteus niger (Stoplight loosejaw)

Argentina silus (Greater argentine)

Nansenia groenlandica (Greenland argentine)

Bathylagus euryops (Goiter blacksmelt)

Mallotus villosus (Capelin)

Scopelosaurus lepidus (Blackfin wrayfish

Benthosema glaciale (Glacier lantern fish)

Lampadena speculigera (Mirror lanternfish)

Lampanyctus intricarius (Diamoncheek lanternfish)

Lampanyctus macdonaldi (Rakery beaconlamp)

Myctophum punctatum (Spotted lanternfish)

Notoscopelus kroyeri (Lancet fish)

Protomyctophum arcticum (Arctic telescope)

Arctozenus rissoi (Spotted barracudina)

Magnisudis atlantica (Duckbill barracudina)

Serrivomer beani (Bean's sawtoothed eel)

Nemichthys scolopaceus (Slender snipe-eel)

Synaphobranchus kaupi (Kaup's arrowtooth eel)

Notacanthus chemnitzii (Snubnosed spiny eel)

Gadomus longifilis (Threadfin grenadier)

Coryphaenoides güntheri (Günther's grenadier)

Coryphaenoides rupestris (Roundnose grenadier)

Macrourus berglax (Roughhead grenadier)

Nezumia bairdii (Marlin-spike grenadier)

Trachyrhynchus murrayi (Murray's longsnout grenadier)

Arctogadus glacialis (Arctic cod)

Boreogadus saida (Polar cod)

Gadus morhua (Cod)

Melanogrammus aeglefinus (Haddock)

Micromesistius poutassou (Blue whiting)

Pollachius virens (Saith)

Trisopterus esmarki (Norway pout)

Brosme brosme (Torsk)

Gaidropsarus argentatus (Arctic rockling)

Gaidropsarus ensis (Threadfin rockling)

Molva dipterygia (Blue ling)

Antimora rostrata (Blue antimora)

Lepidion eques (North Atlantic codling)

Hoplostethus atlanticus (Orange roughy)

Poromitra capito (Ridgehead)

Scopeloberyx robustus (Longjaw bigscale)

Scopelogadus beanii (Bean's bigscale)

\begin{tabular}{|c|c|c|c|c|c|c|}
\hline $\mathrm{p}$ & 3 & 391 & 1460 & 3.1 & 5.4 & 65.536 \\
\hline $\mathrm{p}$ & 6 & 316 & 1281 & 2.0 & 5.6 & 65.551 \\
\hline $\mathrm{p}$ & 1 & 461 & 461 & 2.0 & 2.0 & 65.463 \\
\hline $\mathrm{p}$ & 1 & 873 & 1252 & 0.5 & 3.1 & 65.355 \\
\hline $\mathrm{p}$ & 41 & 218 & 1060 & 2.2 & 5.8 & 65.513 \\
\hline $\mathrm{p}$ & 1 & 391 & 391 & 3.2 & 3.2 & 65.536 \\
\hline $\mathrm{p}$ & 53 & 391 & 1460 & 0.8 & 4.9 & 66.353 \\
\hline $\mathrm{p}$ & 278317 & 155 & 1459 & -0.1 & 5.4 & 70.966 \\
\hline $\mathrm{p}$ & 6 & 873 & 1281 & 0.5 & 4.9 & 65.414 \\
\hline $\mathrm{p}$ & 1069 & 316 & 896 & -0.2 & 5.6 & 71.067 \\
\hline $\mathrm{p}$ & 2 & 391 & 419 & 3.2 & 3.7 & 65.551 \\
\hline $\mathrm{p}$ & 32 & 391 & 813 & 3.2 & 3.8 & 65.536 \\
\hline $\mathrm{p}$ & 19 & 321 & 1281 & 0.8 & 5.4 & 66.353 \\
\hline \multirow[t]{3}{*}{$\mathrm{p}$} & 31 & 164 & 1265 & 1.1 & 5.6 & 66.212 \\
\hline & 9 & 316 & 1460 & 1.1 & 5.6 & 65.478 \\
\hline & 4 & 382 & 1281 & 2.6 & 3.7 & 65.808 \\
\hline $\mathrm{p}$ & 6 & 462 & 910 & 0.8 & 5.2 & 66.353 \\
\hline $\mathrm{p}$ & 51 & 419 & 1281 & 1.1 & 4.9 & 65.551 \\
\hline $\mathrm{p}$ & 7 & 391 & 1257 & 1.9 & 4.6 & 65.551 \\
\hline & 2 & 419 & 1460 & 3.4 & 3.9 & 65.551 \\
\hline & 58 & 631 & 1460 & 2.3 & 5.2 & 65.399 \\
\hline & 14 & 637 & 1460 & 0.5 & 5.1 & 65.513 \\
\hline & 11 & 1252 & 1460 & 3.1 & 3.4 & 62.224 \\
\hline & 44 & 850 & 1460 & 3.1 & 4.9 & 62.392 \\
\hline & 300 & 410 & 1460 & 0.5 & 5.1 & 65.414 \\
\hline & 139 & 327 & 1460 & 0.2 & 5.4 & 68.146 \\
\hline & 5 & 896 & 1257 & 3.0 & 4.0 & 64.972 \\
\hline & 31 & 850 & 1281 & 3.0 & 5.0 & 64.861 \\
\hline $\mathrm{p}$ & 19 & 180 & 569 & 0.1 & 4.7 & 71.695 \\
\hline \multirow[t]{3}{*}{$\mathrm{p}$} & 528 & 164 & 1077 & -0.1 & 5.8 & 71.695 \\
\hline & 165 & 155 & 988 & 0.8 & 5.6 & 67.495 \\
\hline & 262 & 155 & 464 & 0.8 & 5.4 & 66.353 \\
\hline \multirow[t]{10}{*}{$\mathrm{p}$} & 68 & 164 & 988 & 1.5 & 5.5 & 65.982 \\
\hline & 2 & 406 & 422 & 2.1 & 2.2 & 66.215 \\
\hline & 8 & 236 & 426 & 5.1 & 5.4 & 62.216 \\
\hline & 3 & 218 & 709 & 1.9 & 5.4 & 66.215 \\
\hline & 21 & 289 & 1459 & -0.6 & 5.3 & 71.612 \\
\hline & 1 & 287 & 653 & 2.5 & 5.8 & 66.162 \\
\hline & 19 & 218 & 890 & 1.5 & 5.4 & 65.877 \\
\hline & 38 & 850 & 1460 & 3.0 & 5.0 & 64.972 \\
\hline & 11 & 444 & 1265 & 3.1 & 5.2 & 64.966 \\
\hline & 1 & 897 & 897 & 4.4 & 4.4 & 62.198 \\
\hline$p$ & 4 & 391 & 391 & 3.2 & 3.2 & 65.536 \\
\hline $\mathrm{p}$ & 1 & 1072 & 1072 & 3.0 & 3.0 & 64.861 \\
\hline $\mathrm{p}$ & 4 & 419 & 419 & 3.7 & 3.7 & 65.551 \\
\hline
\end{tabular}


Chiasmodon niger (Black swallower)

Aphanopus carbo (Black scabbard fish)

Anarhichas denticulatus (Jelly wolf-fish)

Anarhichas lupus (Wolf-fish)

Anarhichas minor (Spotted wolf-fish)

Leptoclinus maculatus (Spotted snake blenny)

Lumpenus lampretaeformis (Snake blenny)

Gymnelus retrodorsalis (Aurora unernak)

Lycenchelys muraena (Moray wolf eel)

Lycenchelys sarsi (Sar's wolf eel)

Lycodes adolfi (Adolf's eelpout)

Lycodes esmarki (Greater eelpout)

Lycodes eudipleurostictus (Doubleline eelpout)

Lycodes frigidus (Glacial eelpout)

Lycodes luetkenii (Lütken's eelpout)

Lycodes paamiuti (Paamiut eelpout)

Lycodes pallidus (Pale eelpout)

Lycodes reticulatus (Arctic eelpout)

Lycodes seminudus (Longear eelpout)

Lycodes vahli (Vahl's eelpout)

Lycodonus flagellicauda ???

Sebastes marinus (Golden redfish)

Sebastes mentella (Deep sea redfish)

Artediellus atlanticus (Atlantic hookear sculpin)

Artediellus uncinatus (Arctic hookear sculpin)

Icelus spatula (Spatula sculpin)

Triglops murrayi (Moustache sculpin)

Triglops nybelini (Nybelin's sculpin)

Triglops pingeli (Ribbed sculpin)

Cottunculus microps (Polar sculpin)

Cottunculus thomsonii (Pallid sculpin)

Leptagonus decagonus (Atlantic poacher)

Cyclopterus lumpus (Lumpsucker)

$\mathrm{p}$

Eumicrotremus spinosus (Atlantic spiny lumpsucker)

Careproctus reinhardti (Sea tadpole)

Liparis fabricii (Gelatinous snailfish)

Liparis gibbus (Variegated snailfish)

Paraliparis bathybius (Black seasnail)

Paraliparis copei (Blacksnout seasnail)

Rhodichthys regina (Treadfin seasnail)

Glyptocephalus cynoglossus (Witch)

Hippoglossoides platessoides (Long rough dab)

Hippoglossus hippoglossus (Halibut)

Reinhardtius hippoglossoides Greenland halibut)

Lophius piscatorius (Anglerfish)

Cryptopsaras couesii (Triplewart seadevil) $\mathrm{p}$

(10)

\begin{tabular}{|c|c|c|c|c|c|}
\hline 1 & 890 & 890 & 4.9 & 4.9 & 62.392 \\
\hline 1 & 391 & 1072 & 2.9 & 5.1 & 65.536 \\
\hline 4 & 157 & 1072 & 1.1 & 5.5 & 66.215 \\
\hline 19 & 164 & 461 & 2.0 & 5.8 & 66.227 \\
\hline 8 & 190 & 883 & 0.9 & 5.8 & 67.495 \\
\hline 3 & 295 & 295 & 1.3 & 1.3 & 70.412 \\
\hline 1 & 316 & 316 & 5.6 & 5.6 & 62.4 \\
\hline 1 & 287 & 377 & 2.5 & 2.8 & 66.162 \\
\hline 1 & 1260 & 1260 & -0.5 & -0.5 & 71.612 \\
\hline 1 & 417 & 431 & 4.1 & 4.1 & 64.527 \\
\hline 5 & 676 & 1341 & -0.3 & -0.2 & 71.249 \\
\hline 2 & 416 & 692 & 1.1 & 4.1 & 67.899 \\
\hline 10 & 351 & 1088 & 0.2 & 2.1 & 70.597 \\
\hline 2 & 1311 & 1454 & -0.6 & -0.4 & 71.321 \\
\hline 2 & 452 & 452 & 1.1 & 1.1 & 65.93 \\
\hline 5 & 459 & 1343 & -0.5 & 5.4 & 71.612 \\
\hline 6 & 295 & 1123 & -0.3 & 1.3 & 71.249 \\
\hline 6 & 291 & 546 & 0.1 & 3.8 & 70.597 \\
\hline 7 & 381 & 1125 & -0.2 & 1.3 & 71.067 \\
\hline 2 & 268 & 377 & 2.8 & 4.1 & 66.227 \\
\hline 2 & 1260 & 1260 & -0.5 & -0.5 & 71.612 \\
\hline 373 & 155 & 1257 & 0.5 & 5.8 & 67.478 \\
\hline 4011 & 155 & 1460 & 0.5 & 5.8 & 66.365 \\
\hline 10 & 118 & 1077 & -1.2 & 2.8 & 71.692 \\
\hline 13 & 329 & 425 & 1.1 & 5.1 & 66.215 \\
\hline 1 & 328 & 328 & 4.2 & 4.2 & 64.471 \\
\hline 13 & 164 & 988 & 1.1 & 5.4 & 67.478 \\
\hline 96 & 118 & 1077 & -1.2 & 2.5 & 71.695 \\
\hline 4 & 312 & 312 & 0.1 & 0.1 & 68.373 \\
\hline 22 & 118 & 1260 & -1.2 & 5.1 & 71.612 \\
\hline 1 & 1257 & 1257 & 4.0 & 4.0 & 62.288 \\
\hline 4 & 312 & 717 & 0.1 & 2.1 & 70.745 \\
\hline 1 & 157 & 157 & 5.2 & 5.2 & 64.427 \\
\hline 1 & 295 & 459 & 1.0 & 1.3 & 70.412 \\
\hline 6 & 295 & 1125 & -0.2 & 1.3 & 71.067 \\
\hline 20 & 295 & 1088 & -0.1 & 2.3 & 71.692 \\
\hline 3 & 351 & 459 & 1.0 & 1.1 & 70.335 \\
\hline 9 & 1123 & 1459 & -0.6 & 3.9 & 71.321 \\
\hline 3 & 1454 & 1454 & 1.0 & 1.0 & 68.484 \\
\hline 2 & 749 & 1459 & -0.6 & 0.7 & 71.612 \\
\hline 6 & 328 & 811 & 4.1 & 4.2 & 65.161 \\
\hline 50 & 164 & 988 & 0.5 & 5.8 & 71.695 \\
\hline 36 & 157 & 434 & 1.4 & 5.5 & 69.714 \\
\hline 205 & 287 & 1460 & -0.5 & 5.2 & 71.695 \\
\hline 1 & 631 & 631 & 5.2 & 5.2 & 62.297 \\
\hline 1 & 462 & 462 & 0.8 & 0.8 & 66.35 \\
\hline
\end{tabular}




\section{Appendix 2}

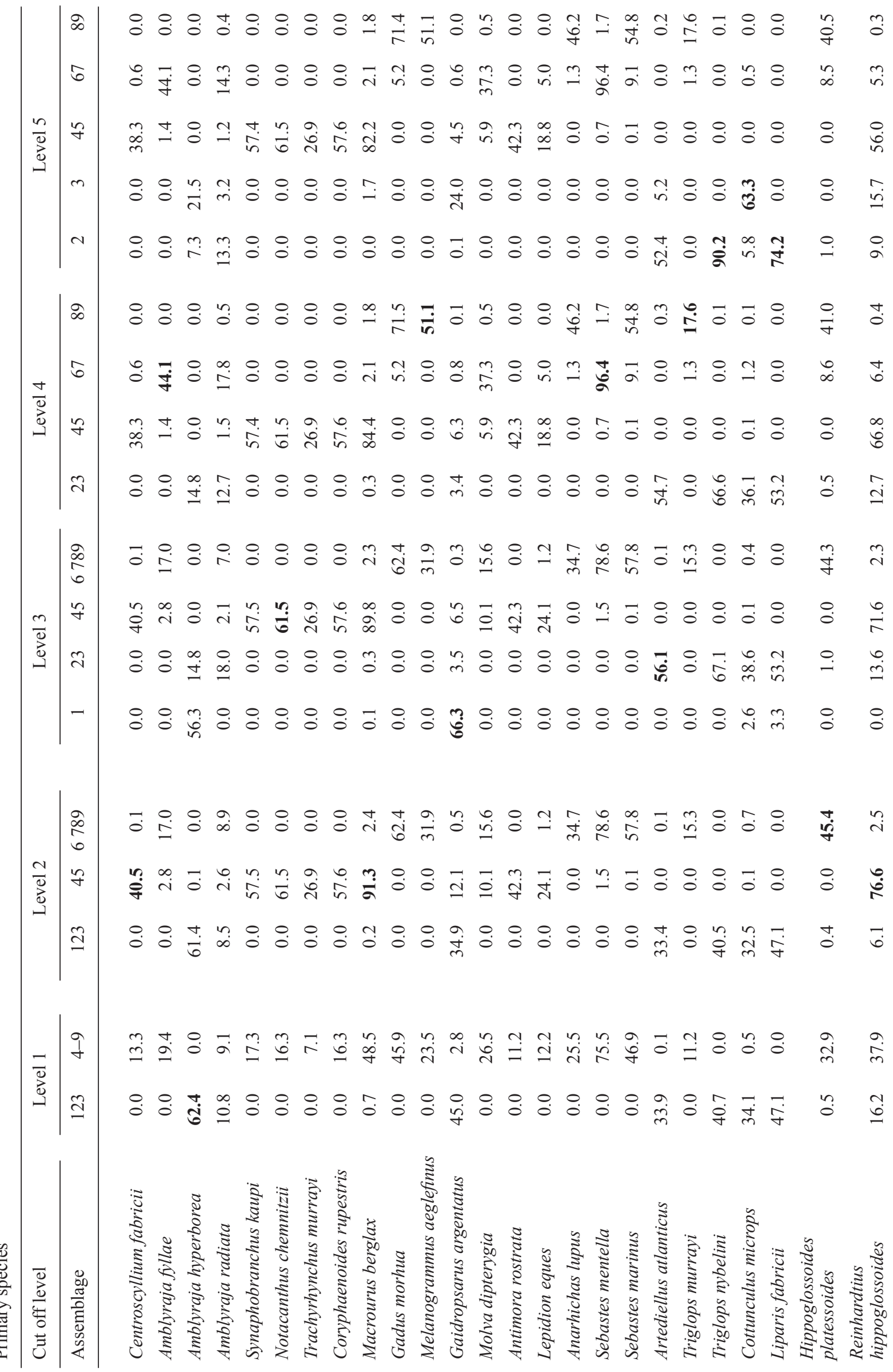




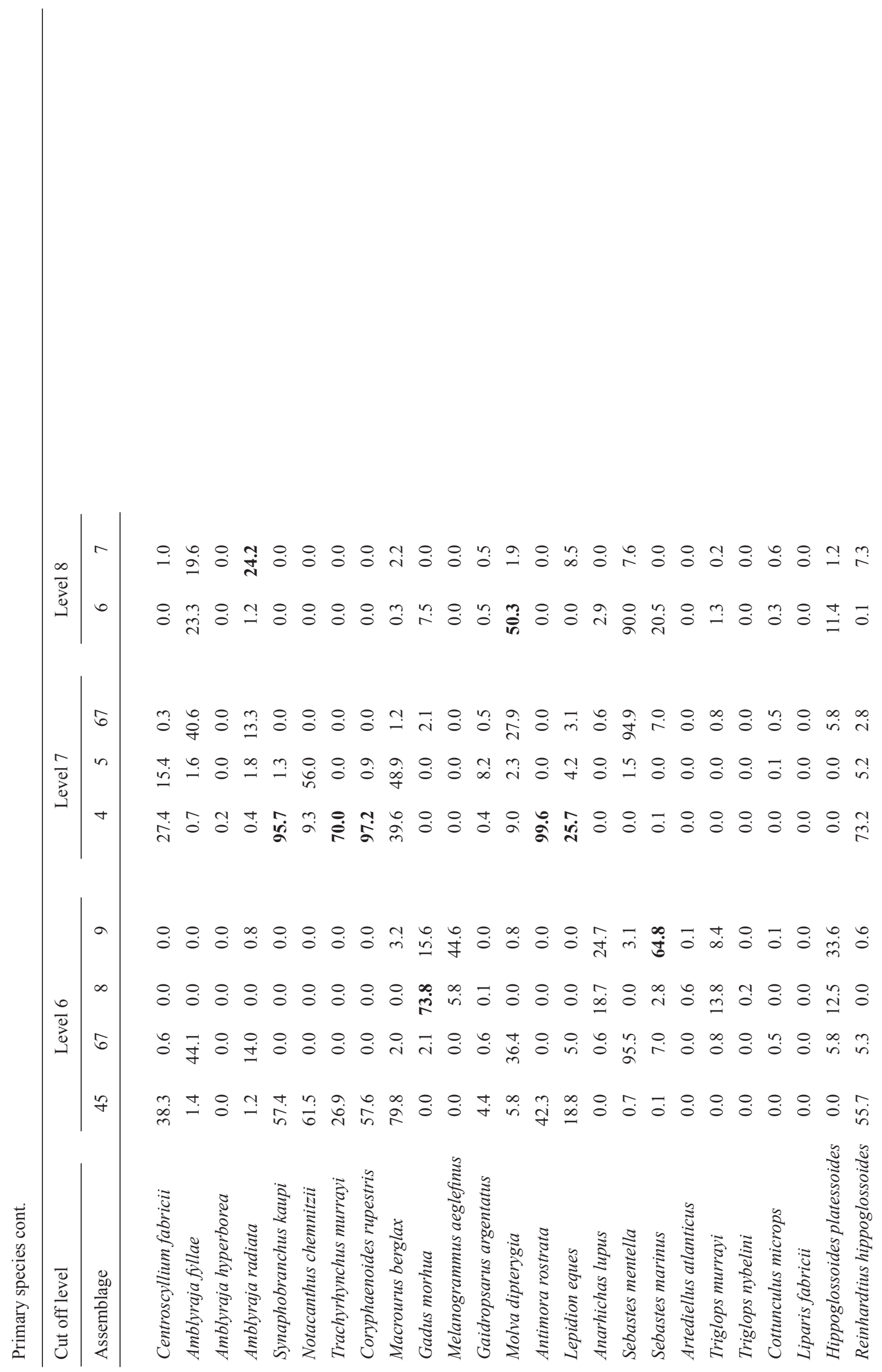




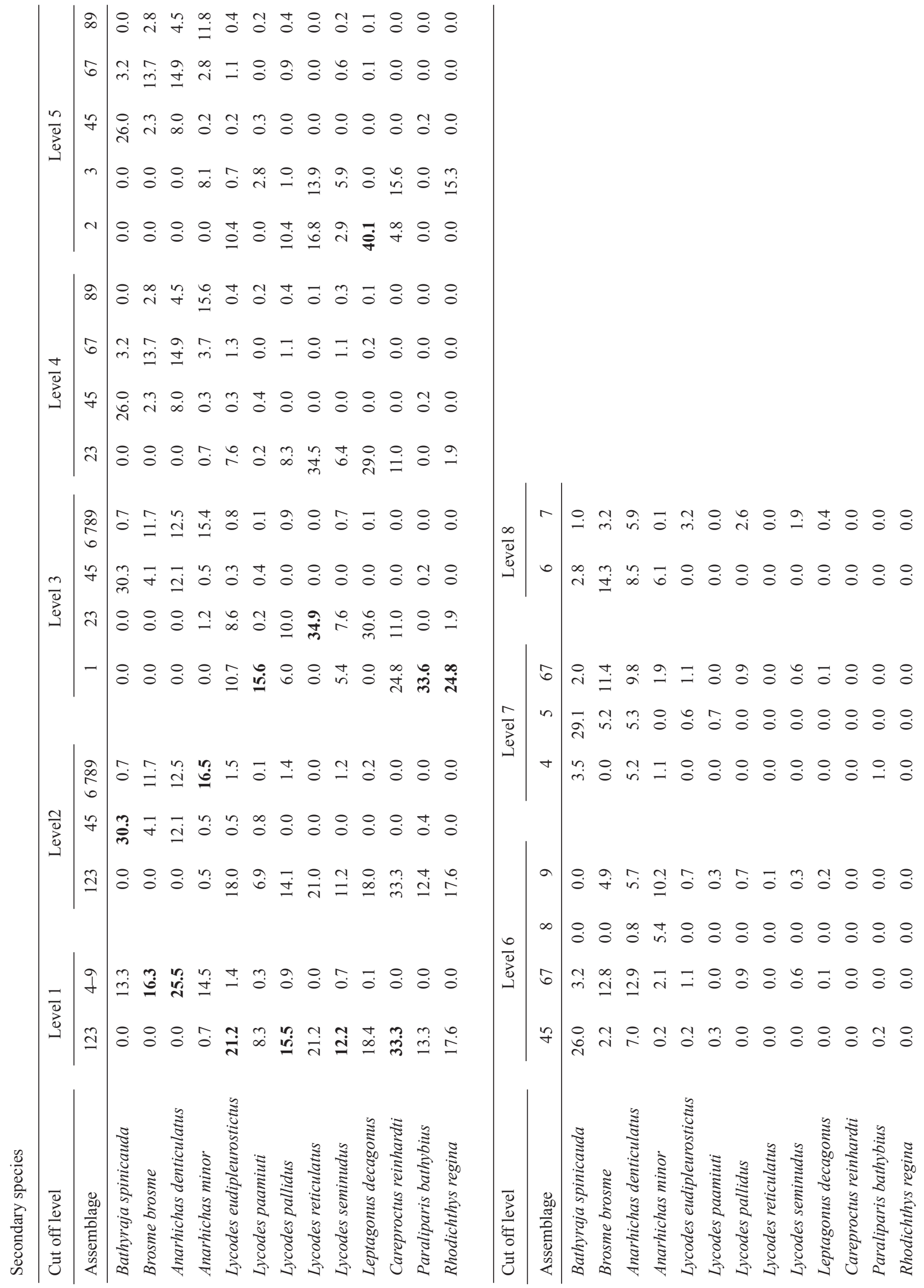

